\title{
Come Rain or Come Shine: \\ Archer M. Huntington between Spain and the United States
}

Patricia Fernández Lorenzo

Universidad Complutense de Madrid 

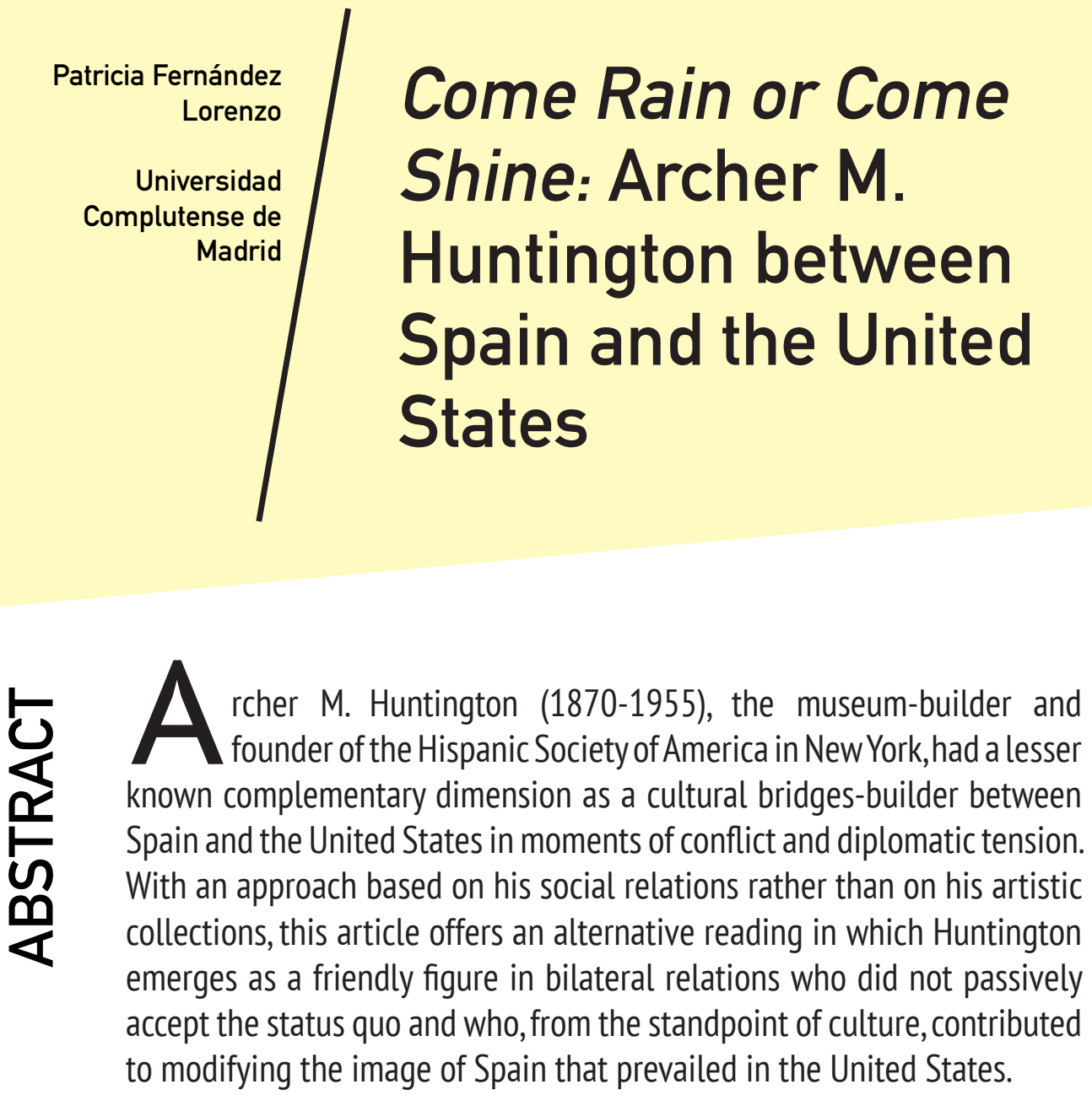

Key Words: Hispanism, Hispanic Society of America, Archer Huntington, Spanish culture, cultural diplomacy, bilateral relations

\section{INTRODUCTION: TO FACE THE CLIMATE}

As it is hard to see the forest for the trees, it seems particularly hard to envisage more than an exquisite art collector in Archer Milton Huntington (1870-1955), the founder of The Hispanic Society of America. The collections he amassed in the museum he founded in New York in 1904

'Fernández Lorenzo, P. “Come Rain or Come Shine: Archer M. Huntington between Spain and the United States”. REDEN.1:1.(2019): 8-26. Web. 
are unparalleled in their scope and quality: holding more than 30.000 objects including paintings, drawings, prints, sculptures, ceramics, ironworks, textiles, jewellery; 175.000 photographs of Spain and Latin America and a library with more than 250.000 books and newspapers, including 15.000 volumes printed before 1701 (Codding). Works by Velázquez, El Greco, Goya and Sorolla hang on its walls today while a copy of El Quijote, unique in the world, is kept on its shelves. It is a collection of incalculable value that covers almost twenty centuries of Iberian history and addresses nearly every aspect of culture in Spain, as well as a large part in Portugal and Latin America. Thanks to Huntington's diaries (1898), we know today that he took on this project guided by the romantic aspiration of condensing the soul of Spain in a museum: "It must condense the soul of Spain into meanings, through works of the hand and spirit"1.

With deep determination and commitment, he advanced Hispanic Studies in the United States more than any other individual during the first half of the twentieth century. Under his own supervision, exhibitions of Spanish artists such as Joaquin Sorolla and Ignacio Zuloaga were presented and more than 200 monographs of Hispanic issues from international scholars were

\section{With deep determination and commitment, he advanced Hispanic Studies in the United States more than any other individual during the first half of the twentieth century.}

published by the Hispanic Society of America as well as through other international magazines he financed. Although he preferred anonymity, it was known that he was also the benefactor of many other cultural institutions and museums through gifts of land and endowments (Mitchell \& Goodrich). The editors of the Hispanic Review summarized his life's work: "There is a massive uniqueness about his long, creative life. It constitutes a single, shining act of unselfish devotion to the civilization of another country and perhaps no other country has been so honoured" (Proske 27).

Nevertheless, apart from the cultural legacy he left, his remarkable accomplishments to improve the relationships between his own country and Spain far exceeded his expert-eye in art collecting.

${ }^{1}$ Huntington Diaries, 1898. Hispanic Society of America: New York. The Diaries are located in the Huntington Archive at the Hispanic Society of America and archived chronologically so date citations are the only form of reference made to these sources. 


\section{Apart from the cultural}

legacy he left, his remarkable accomplishments to improve the relationships between his

$$
\begin{gathered}
\text { own country and Spain far } \\
\text { exceeded his expert-eye in } \\
\text { art collecting. }
\end{gathered}
$$


There are two relevant dates to frame this analysis:

- 1898: The year in which Spain and the United States confronted each other in the Spanish-American War. A young Archer Huntington, aged 28 years, finds himself travelling in Spain doing archaeological excavations in Seville.

- 1953: The year of the signing of the Pact of Madrid to restore relations between Spain and the United States after the period of diplomatic tension that followed the end of World War II. Despite being eighty-three years old and in poor health, Archer Huntington remains a symbol for Spanish culture in the United States and Spanish institutions attempt to regain the American friendship for the Spanish public sphere.

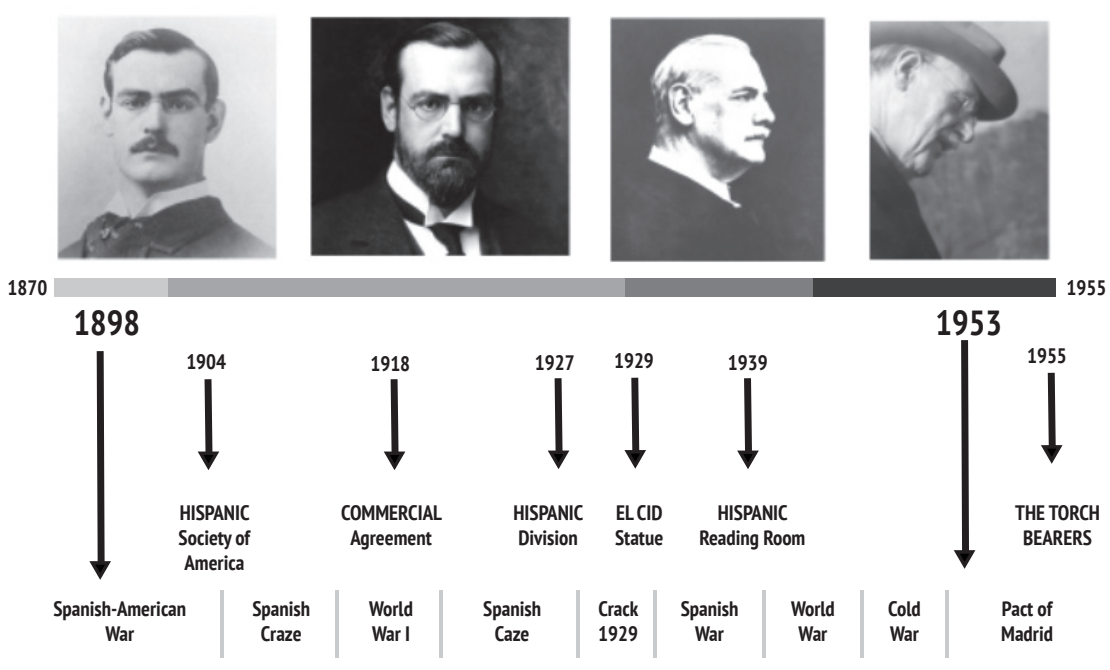

Figure 1. Huntington's time-line

Between the two dates there are almost 60 years of encounters and misunderstandings, of admiration and rejection between the two countries; a period that covers the entire adult life of Huntington. At certain times he stepped forward while, at others, he maintained a more withdrawn stance. His way of dealing with circumstances or, symbolically speaking, to face the climate, is crucial in defining both the character of his Hispanic legacy and its significance in Spanish cultural history. 


\section{BLACK CLOUDS - THE SPANISH-AMERICAN WAR OF 1898}

Archer Huntington, the only son of one of the richest men in America, Collis Potter Huntington -builder of the Central Pacific Railroad and the Newsport News Shipbuilding and Drydock Company-, had already concluded at the age of twenty that he had little interest in the family business, so he dedicated his life to Hispanic Studies and to his project of a Spanish Museum instead. The influence of his devoted mother, Arabella, was decisive on developing his artistic interests.

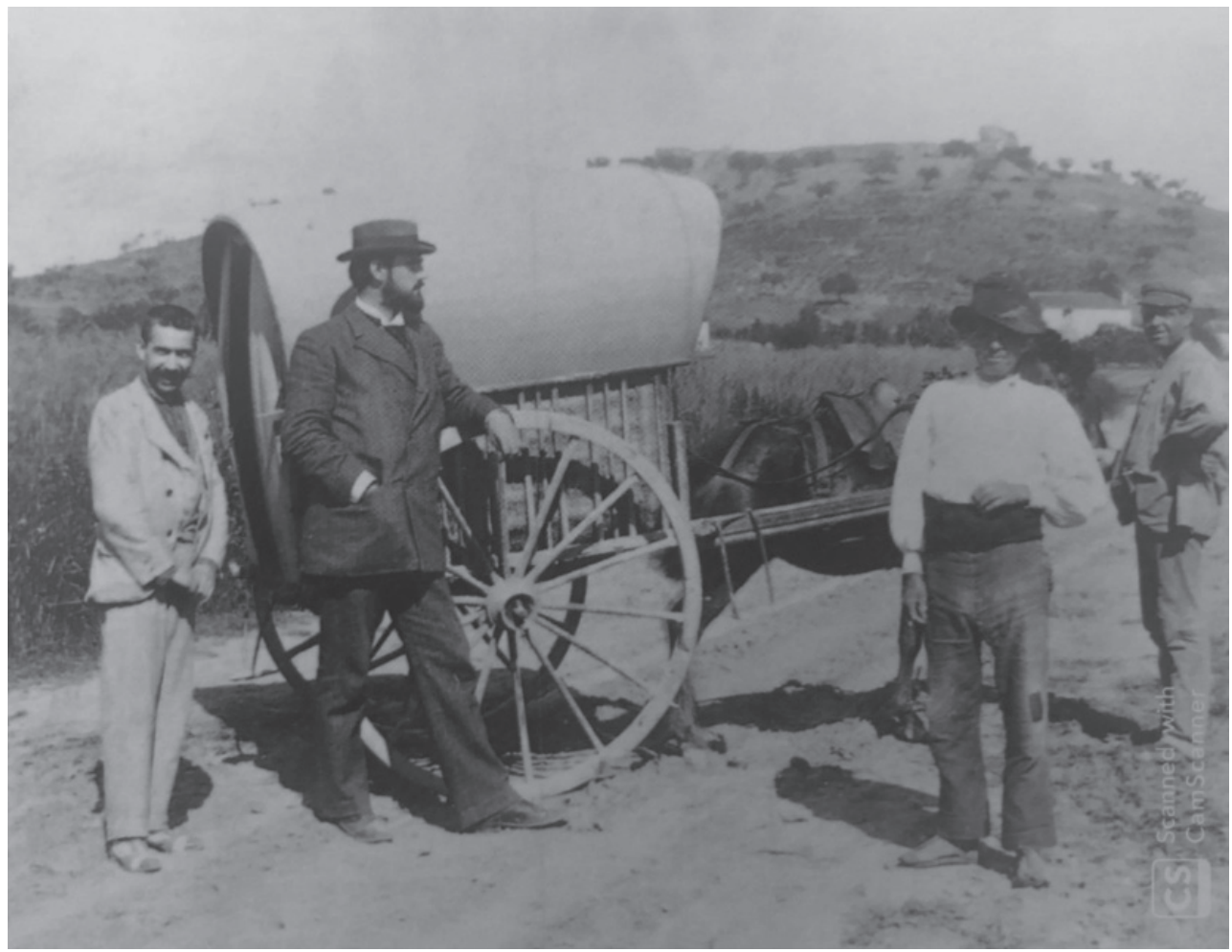

Figure 2. Huntington in Spain, 1892. Source: Courtesy Hispanic Society of America

With this idea in mind, he made his first journey to Spain in 1892; he wanted to see the country and meet its people first-hand, following the steps of the medieval hero El Cid Campeador, whose Poema del Cid he translated into English (Huntington 1897). Coming back to Spain in 1896, he became aware of the emerging climate of tension between Spain and his own country, due to the dissident movements in Cuba and the sympathy the Cuban cause had aroused in the United 
States. At such a time, in the midst of the confusion created by the United States' offer of mediation for the negotiation of independence, statements by Huntington from Spain appeared in the New York Herald of April $6^{\text {th }}, 1896$. In the words of the journalist, Huntington was positive in his belief that Spain was right and that her course was perfectly justifiable in the Cuban affair. In case of

\section{Published in 1898, his book A Note-book in Northern Spain offered an image of Spain that was very different from the one spread by American newspapers, which was mainly based on the anti-Spanish sentiment known as the "Black Legend}

war, Huntington said, his sympathies would be with his native land but he earnestly believed that the United States was entirely wrong and had no right to interfere in the Cuban rebellion. He was convinced that the United States would ultimately win, but that Spain would put up a good fight (New York Herald).

His controversial statements to the press were not well received either in his country, where a powerful patriotic feeling was emerging, or by his family. However, they have great documentary value in bringing to light the process of growing Hispanophilia that he was experiencing while the US press launched a smear campaign against everything that had to do with Spanish history and the represented culture.

In spite of the circumstances, Huntington returned to Spain in 1898 to carry out archaeological excavations in Seville (Tesoros arqueológicos de la Hispanic Society). Four months later he was forced to leave the peninsula by the declaration of war between the United States and Spain. In the telegrams he exchanged with his mother, he conveyed the climate of concern that, after the explosion of the Maine, many people felt in Spain, although the Spanish press, encouraged by the patriotic outburst, irresponsibly defended the idea that the war could be won with relative ease (Arranz Notario). Huntington went back home, utterly frustrated with the situation as the war, understandably, put an end to his archaeological plans. Nevertheless, vivid impressions of some of the places he had seen on his trips went into A Note-book in Northern Spain. Published in 1898, the book offered an image of Spain that was very different from the one spread by American newspapers, which was mainly based on the anti-Spanish sentiment known as the "Black Legend" (Roca Barea). ${ }^{2}$

2 The Black Legend is a term indicating an unfavourable image of Spain and Spaniards accusing them of inhumanity, cruelty, intolerance, backwardness and other failings of the Spanish nation as a whole, formerly prevalent in the works of many non-Spanish historians. The term was popularized by the Spanish historian Julián de Juderías in his book La Leyenda Negra, in 1914. 
With his book, Huntington proved that he promoted an erudite appreciation and a serious approach to Spanish history and culture. But he also showed concern for the weak national consciousness that existed in Spain due to identity differences between its regions ${ }^{3}$, which could negatively influence an unstable policy of national unity: "She [Spain] is in more than one sense a composite nation, and such is the more difficult to see and know as a whole. Cataluña,Aragon, Castile,Andalucía, are not mere geographical terms. Each presents its distinct national character" (Huntington 1898: 3). The year 1898 became a symbol of the decline of Spain and of the rise of the United States as a superpower in the international scene, but it was also a crucial moment in Huntington's career as a Hispanist. By that time Huntington knew and loved Spain.

\section{SUNNY WEATHER - THE HISPANIC SOCIETY OF AMERICA AND THE SPANISH CRAZE}

Although it seems paradoxical, the height of Spain's cultural influence in the United States took place few years after the brief 1898 war, during the so-called Spanish Craze (Kagan). Art, music, architecture, films and literature from Spain fascinated America between 1898 and the beginning of the Spanish Civil war. For the majority of the American collectors of the Gilded Age, to possess the treasures of Spain was a symbolic way to confirm the rise of the new American empire and the decline of the old Spanish one (Jiménez-Blanco). This was not the case for Huntington. The large inheritance he received after his father's death in 1900 allowed him to fulfill his dream: to found the Hispanic Society of America, an institution dedicated to advancing the study of Spanish and Portuguese languages, literature, and history in order to make the patrimony known to the American audience.

As it is known that he toiled over the precise wording of constitution and bay-laws (Proske), a deep study of the text of the Founding deed reveals that his aim was more ambitious: "This instrument provides for the establishment in the city of New York of a public Spanish and Portuguese Library and Museum, to be in some measure a link between the English and the Spanish-speaking peoples".

While the Hispanic Society helped to increase American society's interest in Hispanic culture with Sorolla's or Zuloaga's exhibitions and the publication of books, Huntington established friendly relations with illustrious Spaniards during his trips to Europe. Aristocrats, artists, writers, academics and politicians formed a part of his Spanish friendships. After reading his epistolary testimonies, it is evident that Huntington moved with ease in both court and intellectual circles; if with the former he shared social status and philanthropic aspirations, then with the latter he

\footnotetext{
${ }^{3}$ Huntington's concern nailed down when he commissioned Joaquín Sorolla to decorate the library of the Hispanic Society with fourteen panels representing the different regions of Spain. This mural decoration is entitled Vision of Spain.
} 


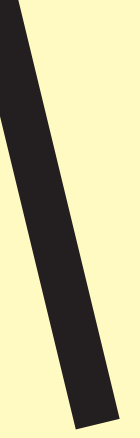

His high level of interlocution with Spanish elites explains

the fact that, at the request of his country's ambassador to Spain, Joseph E. Willard, Huntington participated in the US government delegation to negotiate the trade agreement with Spain of March 7th, 1918, in the middle of World War I. 
shared the interests of the scholar of the arts, literature, archaeology or Spanish history. Huntington as patron and Huntington as scholar both had their place in Spain. His financing of the Casa-Museo del Greco in Toledo, the Casa-Museo de Velázquez in Valladolid, the Museo del Romanticismo in Madrid, his donations to the Archaeological Museum of Seville or his participation as patron in the Valencia de Don Juan Foundation were the result of these close friendly relations with the Marquis de la Vega-Inclán, Sorolla, the Duke of Alba, Guillermo de Osma, Gregorio Marañón or Menéndez Pidal, amongst many others. His friendship with the King Alfonso XIII, with whom he had the opportunity to meet on several occasions and from whom he received numerous honours for his services to Spanish culture, is of special interest (Fernández Lorenzo).

\section{With the Hispanic Division in the Congress Library, in Washington. Huntington added a note of excellence to Hispanic studies at a time when they were being questioned if not directly attacked. One again, he lobbied to defend Hispanicism with the weapons he knew best, the academic institutionalization of culture.}

His high level of interlocution with Spanish elites explains the fact that, at the request of his country's ambassador to Spain,Joseph E. Willard, Huntington participated in the US government delegation -together with army general August Belmont- to negotiate the trade agreement with Spain of March $7^{\text {th }}, 1918$, in the middle of World War I. By virtue of this agreement, the Spanish Government, neutral in the conflict, agreed to grant export licences for various articles in order to cover the needs of the American Expeditionary Force during the war, and allowed unrestricted exportation of certain minerals to the United States. In return, the United States authorized the sale of cotton and oil to Spain, which were essential to supply the Spanish industry (Montero Jiménez). Huntington was an illustrious scholar with no political ambitions, but they turned to him to facilitate trade agreements in times of war as much as possible. Perhaps this is the best demonstration of the value his own government placed on the "cultural ambassador" work that Huntington had been doing from the Hispanic Society in the early decades of the century.

The Great War resulted in a decrease of interest in studying German, which directly benefitted the increase in the study of Spanish in the United States. Huntington supported the creation of the American Association of Teachers of Spanish (AATS) in 1916, whose New York delegates held their meetings precisely in the halls of the Hispanic Society. The new demand of teachers for so many students was so unexpected that the Junta de Ampliación de Estudios and its delegate in New York, Federico de Onís, also managed to capitalize on part of the language teaching in the United States with teachers from Spain. However, the rapid popularization of 


\section{During the Spanish Civil War Huntington assumed a neutral position as he wrote to his friend the Duke of Alba: "As you know, I am forced to be entirely neutral as to Spain- which I am not. But the Hispanic Society is representative of both sides".}

Spanish among the American population made it difficult to combine its populist and functional aspect as a vehicular language for Latin America with the prestige of Hispanic Studies that, at a more elitist level, Huntington and other American Hispanists had been cultivating (Fernández)'

This double approach was also reflected in some public demonstrations in which Spanish was described as a practical and easy to learn language to serve business in Latin America but without a cultural value comparable to French, German or Italian. The teacher of Spanish Henry Grattan Doyle wrote to Huntington in 1926 asking for help to respond to these attacks but in his correspondence Huntington explained which, in his opinion, was the best way to respond to such offenses: "It seems the time for those interested in Spanish to stand together and by example more than advice or resistance to present the cultural and other advantages of the Hispanic field in America"6.

The reference to unity of action was symptomatic of the growing division among American Hispanists between those who favored Pan Americanism and those who did not. However, Huntington decided to promote a new project for the institutionalization of Hispanicism in the United States at the highest level by creating the Hispanic Division at the Library of Congress in Washington in 1927.

In 1926 Herbert Putman, librarian of the Congress, published a desiderata list with the bibliographical documents that should be represented in the Library of the Congress of the United States. The list, which included, among others, the diary of Christopher Columbus' first trip to America in 1493, served to focus on the collection of Portuguese-Spanish publications that the Library of Congress wanted to acquire by means of donations and gifts. In 1927,Archer Huntington was the first to make an endowment for the creation of a Hispanic Division for fifty thousand dollars -equivalent to seven hundred thousand dollars today-, to acquire books of art, literature, history and Hispanic culture in general. A year later, in 1928, he made another endowment of fifty thousand dollars to hire a consultant to be in charge of the selection of books in the new Chair of

\footnotetext{
${ }^{5}$ Referring to this subject, the historian James Fernández has coined the expression "Ley de Longfellow".

${ }^{6}$ Letter of Archer Huntington to Henry Grattan Doyle, March 2nd, 1926. Anna Hyatt Huntington Papers. Special Collections Research Center. Syracuse University Library. Box 31.
} 
The numerous projects he conducted for the internationalization of Spanish culture in the United States and for the revaluation of Spanish cultural heritage made him an unofficial ambassador for cultural diplomacy. 


\section{REDEN}

the Literature of Spain and Portugal in the Library of Congress. Huntington offered the position to his friend, the former Spanish Ambassador to the United States, Juan de Riaño (Dorn).

Book purchases for the Hispanic Division were initially restricted to the Iberian Peninsula. This fact was confirmed by the declarations of Riaño's replacement in office, Father David Rubio -librarian between 1931 and 1943 and curator of the Portuguese-Spanish collections between 1939 and 1943- Speaking of the generous amount donated by Huntington to buy books on art, literature, history and culture of the Iberian Peninsula, he stated that "the other Spanish and Portuguese speaking communities were not included in the original donation clause". In fact, he described how after five years of work in the Library of Congress they managed to amass a collection of one hundred thousand titles by 1935, among which "of Hispanic America there was not even a single volume of Rubén Darío" (Rubio 1957: 35-36).

Having the Hispanic Division within one of the most prestigious institutions in the United States, Huntington added a note of excellence to Hispanic studies at a time when they were being questioned if not directly attacked. Once again, he lobbied to defend Hispanicism with the weapons he knew best, the academic institutionalization of culture.

While this was happening in the United States, an authoritarian regime, led by General Primo de Rivera, had been in place in Spain since 1923, and the position of the monarchy was being questioned by political and intellectual circles. The friendship and respect he professed for the king led Huntington to expressly support two of Alfonso XIIl's most important cultural initiatives:

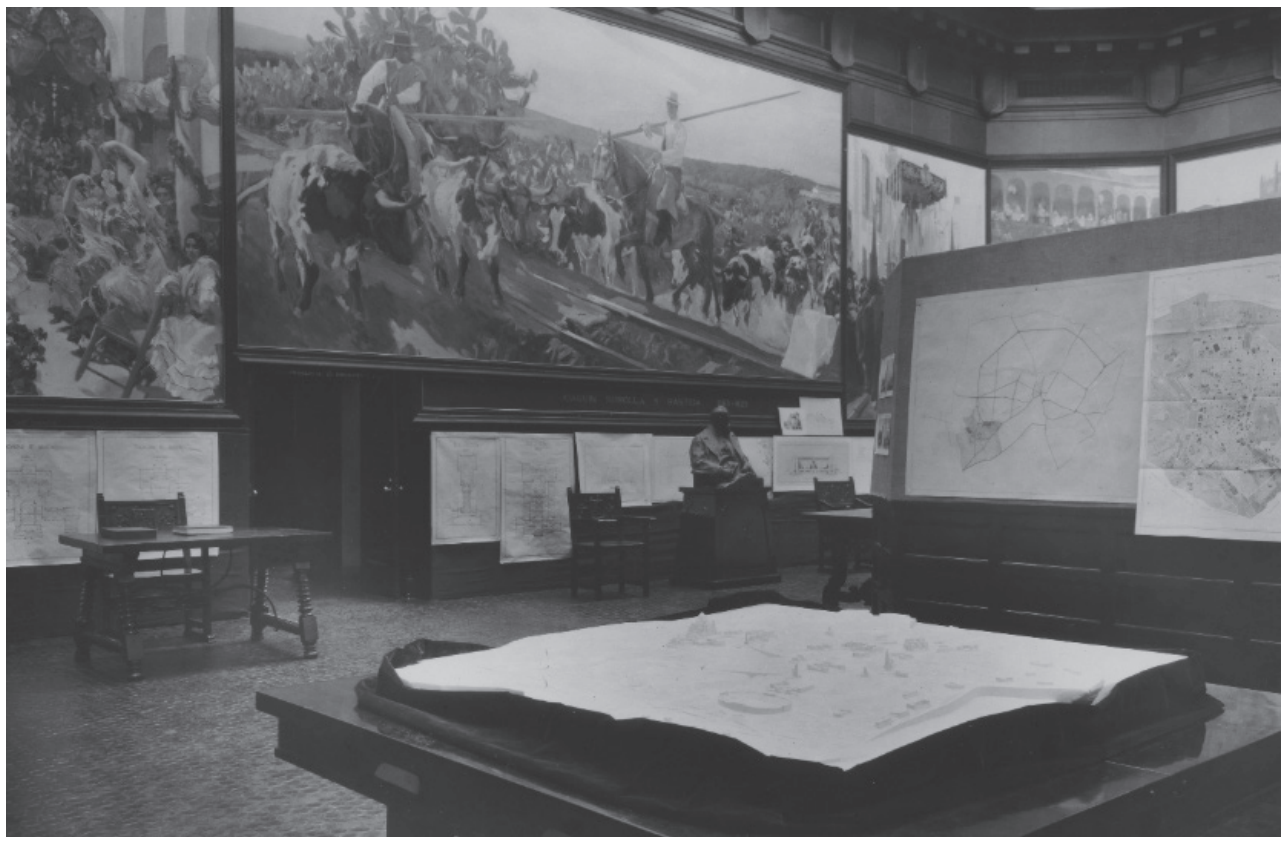

Exhibition of the Project "Ciudad Universitaria de Madrid". Sorolla Room, Hispanic Society of America, 1928. Source: Courtesy Blanca Pons-Sorolla 
On the one hand, the works of the new Ciudad Universitaria of Madrid. Huntington became one of his patrons by creating an endowment worth one hundred thousand dollars- equivalent to almost one and a half million dollars today - to finance the works and by setting up an American Poetry Chair at the Central University of Madrid. In addition, the Sorolla Room of the Hispanic Society in New York, where the Panels of the Regions painted by Sorolla were exhibited, hosted the exhibition of plans and models taken to the United States by the University's Construction Board to make the project known to experts from American universities and foundations.

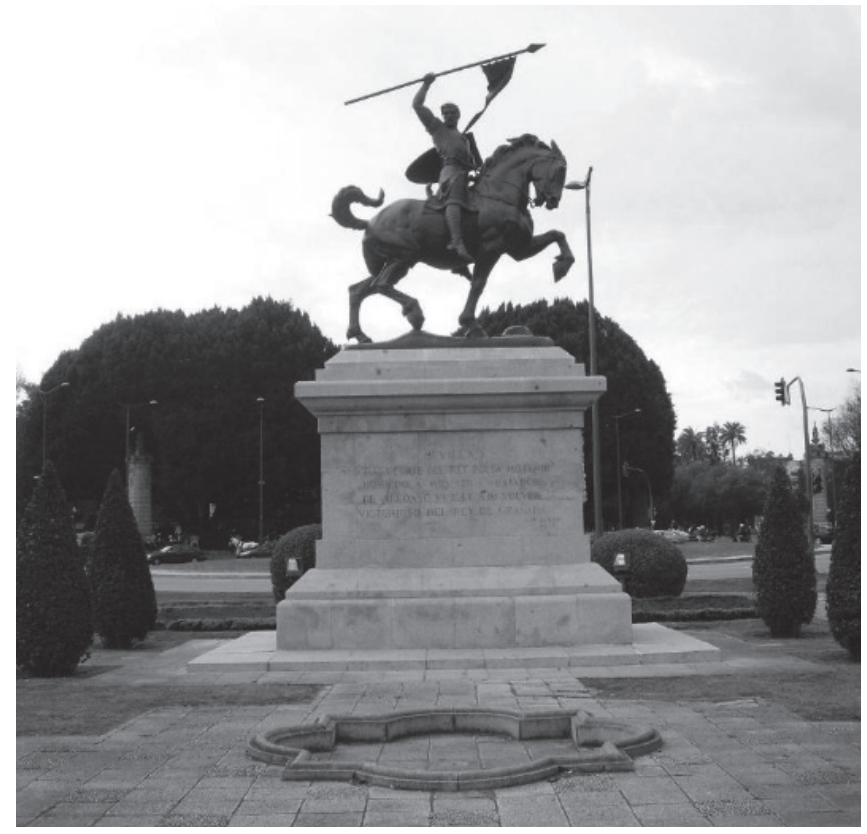

El Cid Campeador by Anna Hyatt. Sevilla

A year later, on the occasion of the 1929 Ibero-American Exhibition in Seville, he also gave clear evidence of his support for the monarch's initiative by giving the city the sculpture of the horseback Cid Campeador, created by his wife Anna Hyatt, which was placed in the square that welcomed those attending the exhibition. The American and his wife attended the inauguration, met Alfonso XIII, donated two paintings by Valdés Leal to the city museum and were named Honorary Citizens of Seville?.

Two years later, after the 1931 local elections, the Second Republic was established in Spain and the king left the country on his way to exile.

\footnotetext{
${ }^{7}$ Marquis de la Vega-Inclán to Alfonso XIII (note). April 15 ${ }^{\text {th }}$, 1927. Archivo General de Palacio. Reinados. Alfonso XIII. Expediente $12422 / 8$.
} 


\section{A PERFECT STORM - THE SPANISH CIVIL WAR}

The outbreak of the Spanish Civil War posed difficult dilemmas for the scholars who dedicated their lives to the study and dissemination of Spanish culture (Faber). Huntington's case was no different from that of many other American Hispanists who found themselves in the uncomfortable position of being compelled to stand for or against one of the two warring sides: the Nationalists or the Republicans. Taking sides in the Spanish conflict went against the Government's official stance of neutrality even though the Spanish Civil War polarized American society very quickly. In fact, the reluctance of American Hispanists to participate in public discussions about Spain was a common behaviour during the war and, as a result, many of them embraced Pan Americanism and focused their new subjects of study in Latin America.

Huntington assumed a neutral position as he wrote to his friend the Duke of Alba: "As you know, I am forced to be entirely neutral as to Spain- which I am not. But the Society is representative of both sides". He was aware that the Hispanic Society was a cultural institution that could easily be compromised by the propaganda appeals of the two opposing sides. Therefore, from the highest political correctness -and perhaps also from his own conviction- Huntington publicly aligned himself with the majority of American Hispanism that opted for public silence.

During the three years of war he exchanged letters with his Spanish friends who, for different reasons, had been aligned on one side or the other; some remained in Spain and told him about the destruction of the artistic historical heritage such as the writer Concha Espina or the painter José López Mezquita; others announced their exit into exile, such as the painter Miguel Viladrich. Under the new circumstances, the Hispanic Society closed its doors to the public. But after the end of the Spanish war, and on the eve of World War II, Huntington stepped forward and showed that his commitment to the erudite Hispanicism he had cultivated remained alive despite the disastrous circumstances. In 1939 he made the decision to fund the construction of the Hispanic Reading Room in the Library of Congress, a special reading and study room for Hispanists who were not going to find many options for research in post-war Spain.

The Hispanic Reading Room, designed by the architect Paul Philippe Cret in Spanish colonial style, opened on October 12th, 1939. Huntington commissioned a mural with Christopher Columbus' coat of arms for the south wall of the room. However, the room became, through the intermediation of the U.S. Secretary of State, the main iconographic exponent of the U.S. Government to symbolize the Pan Americanist spirit. Nelson Rockefeller, director of the Office for the Coordination of Inter-American Affairs, commissioned Brazilian artist Candido Portinari to decorate the room with murals. His designs plastically constructed a multicultural hemispheric identity and a common past that united all American communities (Serviddio).Although Huntington did not participate directly in these decisions, this circumstance allowed him to demonstrate his patriotism at the beginning of World War II but also allowed him to maintain his independence for the Spanish legacy at the Hispanic Society of America in New York. 


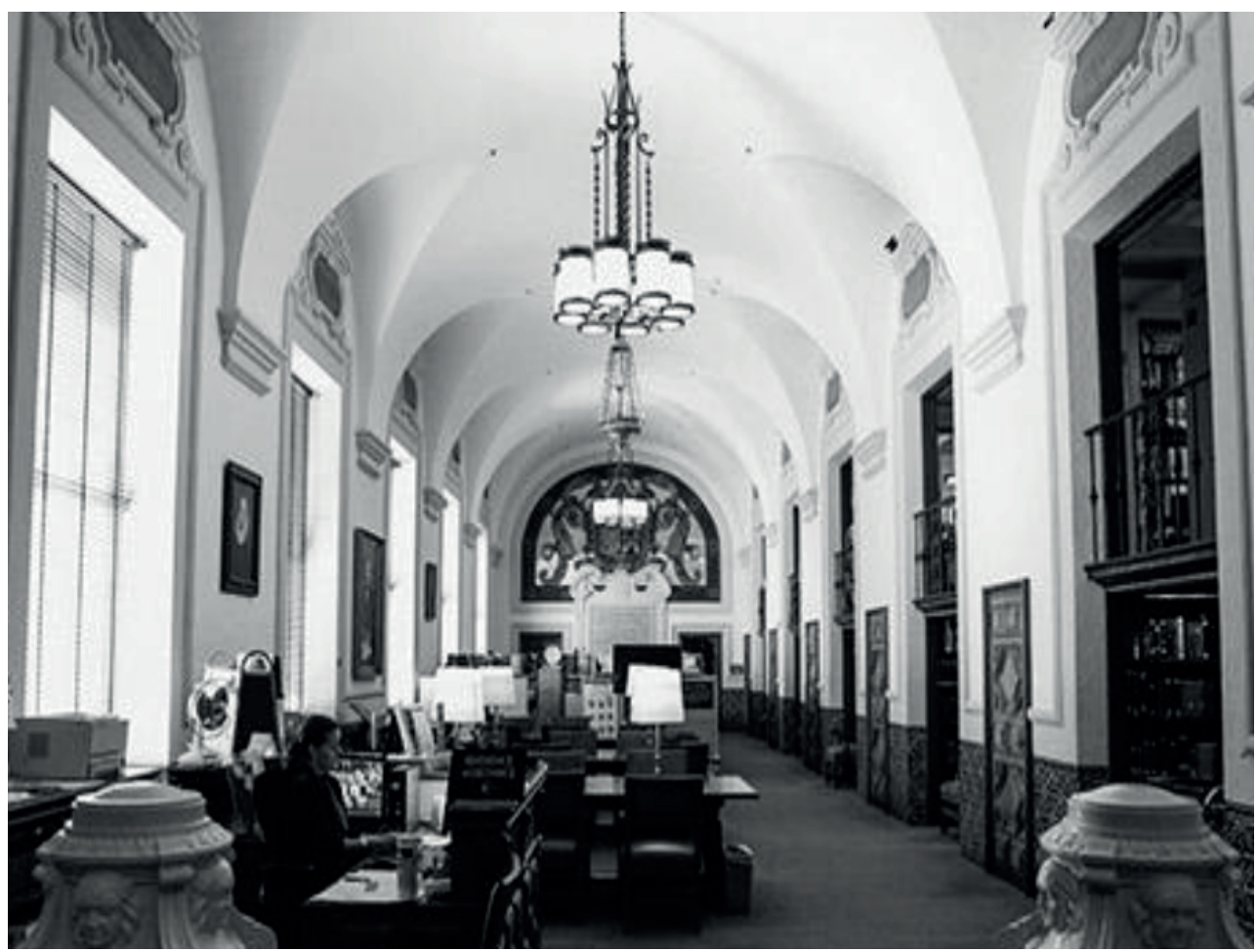

Hispanic Reading Room, Library of Congress, Washington

Huntington accepted the Secretary of State's proposal that the Hispanic Reading Room focus its bibliographical and editorial interests on the Latin American republics, while the Hispanic Society would focus on Spain and its empire before independence ${ }^{10}$. By doing so, he isolated his collection and his New York institution from possible political interference at a time when Washington was not looking favourably on the Franco regime for its ideological approach to the Axis forces.

Given these circumstances, and despite of his disappointment, Huntington's promotion of Spanish studies did not stop. The staff of the Hispanic Society, composed of professional women who were to become experts in their fields, went on with their job under his personal supervision. The news about the outbreak of the World War II depressed him and he decided to move to a country house in Connecticut. From his new emplacement Huntington kept in touch with the many institutions he supported and devoted his time to writing poetry. Some of the titles he published such as Spain and Africa (Huntington 1943), Recuerdos (Huntington 1949), or Versos (Huntington 1952), reveal his constant though on Spain ${ }^{10}$.

${ }_{9}^{9}$ Archer Huntington to Archibald McLeish (letter). June 10 ${ }^{\text {th }}, 1940$. Anna Hyatt Huntington Papers. Special Collections Research Center. Syracuse University Library. Box 43.

${ }^{10}$ Archer Huntington published twenty eight books of poetry between 1936 and 1954. He gathered together many of them and reprinted a volume entitled Collected Verse in 1953. 


\section{A RAY OF SUNSHINE - PACT OF MADRID OF 1953}

Relations between Spain and the United States were weakened after the end of World War II and Spain was consigned to international ostracism. However, the Cold War and the desire to stop the spread of communism encouraged the interest of the United States to collaborate militarily with the Franco regime. The signing of the Pact of Madrid in 1953 for the establishment of military bases on the peninsula allowed for new diplomatic channels to be opened.

At that moment, an unexpected interest arose among the Franco authorities to regain contact with the elderly Hispanist and to bring him closer to Spain. References to Spain's beloved American friend began to appear in the Spanish press ( $A B C$; Espina). It seems important to point out that, since 1948, Huntington had been awarding the Hispanic Society Medals to Spanish intellectuals, some of whom were in exile in America, such as Rafael Altamira,Juan Ramón Jiménez, Ramón Pérez de Ayala and Pau Casals. He had also rewarded intellectuals who had remained in Franco's Spain, such as Francisco Sánchez Cantón, Manuel Gómez-Moreno, Gregorio Marañón, and others without the deserved recognition, as it was the case of José Ortega y Gasset (Hispanic Society of America). Several exiled intellectuals, professors at American universities, wanted to respond to this gesture by paying tribute to him at Wellesley College, a women's university of which Huntington was one of its most discreet patrons. A volume of Estudios Hispánicos dedicated to Archer Huntington on his eightieth birthday was published in Mexico with the contribution of international Hispanists, among them Ramón Ménedez Pidal, Pedro Salinas and Homero Serís (Wellesley College).

The Spanish authorities wanted to prevent him from being portrayed as an icon by moderate groups in exile, and the Instituto de Cultura Hispánica and the Ministry of Foreign Affairs took steps in order to get closer to the Hispanist ${ }^{11}$. Huntington was then eighty-three years old, sick and isolated from cultural life in Connecticut, but he had not forgotten Spain. As a result, recognitions and tributes were paid to the Huntington marriage. In Barcelona, a monument in their honour was inaugurated in the Pedralbes gardens (Socias Batet). Shortly afterwards, the University of Salamanca named them both Doctor Honoris Causa, and Anna Hyatt was granted the additional title of Corresponding Member of the Academia de Bellas Artes de San Jorge. The Universidad Central of Madrid inaugurated the Huntington Chair of American Poetry at the Faculty of Philosophy and Literature in 1954.

In gratitude, Huntington decided to donate the sculpture of Los portadores de la antorcha, sculpted by his wife Anna, to the Ciudad Universitaria of Madrid, as a symbol of friendship between the United States and Spain. Some verses he wrote were engraved on the base of the sculpture.

The U.S. ambassador to Spain participated in the presentation of Los portadores de la antorcha in Madrid on May 15 ${ }^{\text {th }}, 1955$, along with the ministers of Education and Foreign Affairs, the University Dean and Carmen Polo,Franco's wife. In this act, the ambassador declared that Archer

${ }^{11}$ Román de la Presilla, cónsul of Spain in New York, to Juan de Bárcenas, General Director of Foreign Affairs (report). February 2 ${ }^{\text {nd }}$, 1954. AMAEC R. 3585, Expediente 28. 
Huntington had been an unofficial ambassador for years, dedicated to strengthening ties between the two countries. If the non-presence of foreign ambassadors in Spain had been one of the most obvious evidence of his international isolationism, to evoke the stamp of an ambassador referring to Huntington was to grant him publicity and express recognition by the highest representative of US diplomacy of having been a valuable link between the two countries.

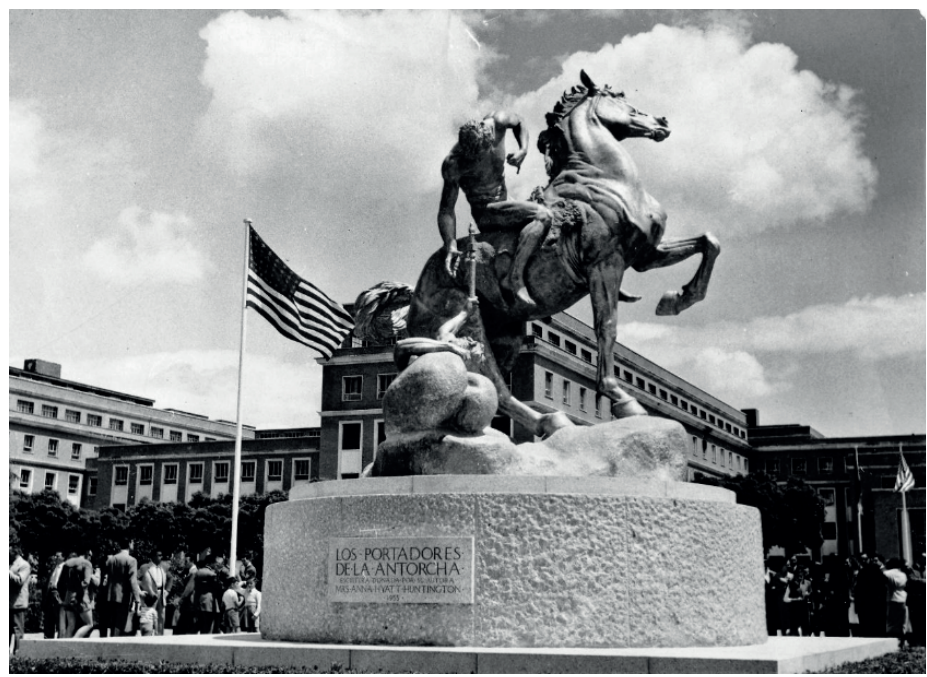

Los portadores de la Antorcha by Anna Hyatt. Ciudad Universitaria de Madrid, 1955.

Source: Agencia Española de Cooperación Internacional para el Desarrollo: AECID. Biblioteca (MH-68/47)

After Huntington's death on December 11th, 1955, the Spanish authorities promoted the establishment of the Huntington Foundation in the Ciudad Universitaria of Madrid as a postgraduate center in North American studies, hoping to get funding from his widow, Anna Hyatt. Despite the interest of the project, unfortunately it did not get off the ground.

The erection of a monument in honour of the Huntingtons was another project undertaken in the 1960s. An Interministerial Commission was created at the highest level, chaired by the head of the Instituto de Cultura Hispánica, Gregorio Marañón Moyá, son of the prestigious physician Gregorio Marañón. The sculptor Juan de Ávalos was even commissioned to design the monument. Due to different circumstances, this project did not succeed either.

1960s Spain, wrapped up in its own affairs, was forgetting the philanthropist Archer M. Huntington, the Hispanic millionaire who never sought public recognition but worked to build bridges between Spain and the United States.

\section{CONCLUSIONS - COME RAIN OR COME SHINE}

Archer Huntington was the great American patron of Spanish culture. The numerous projects he conducted for the internationalization of Spanish culture in the United States and 
for the revaluation of Spanish cultural heritage made him an unofficial ambassador for cultural diplomacy. The personal relationships that he established and the way that he imprinted his work kept him apart from other collectors and Hispanists who, after a period of great attraction, left behind their love for Spain and chose to embark on other journeys. Unlike them, Huntington maintained his devotion to Spain and its culture despite the circumstances or, as the title Come Rain or Come Shine suggests.

In his eighty-five years of life, he launched numerous initiatives to bring the United States and Spain closer culturally, two different worlds that went through moments of closeness and separation, of collaboration and confrontation due to political and cultural circumstances that had a direct impact on the place that Huntington could hold in the changing Spanish scenario. With his actions and omissions, Huntington stands out as a cordial figure in bilateral relations, but also as a personality who did not passively accept the status quo and, from the point of view of friendship and culture, contributed to breaking down walls and linking cultures, seeking to modify the image of Spain that prevailed in the United States.

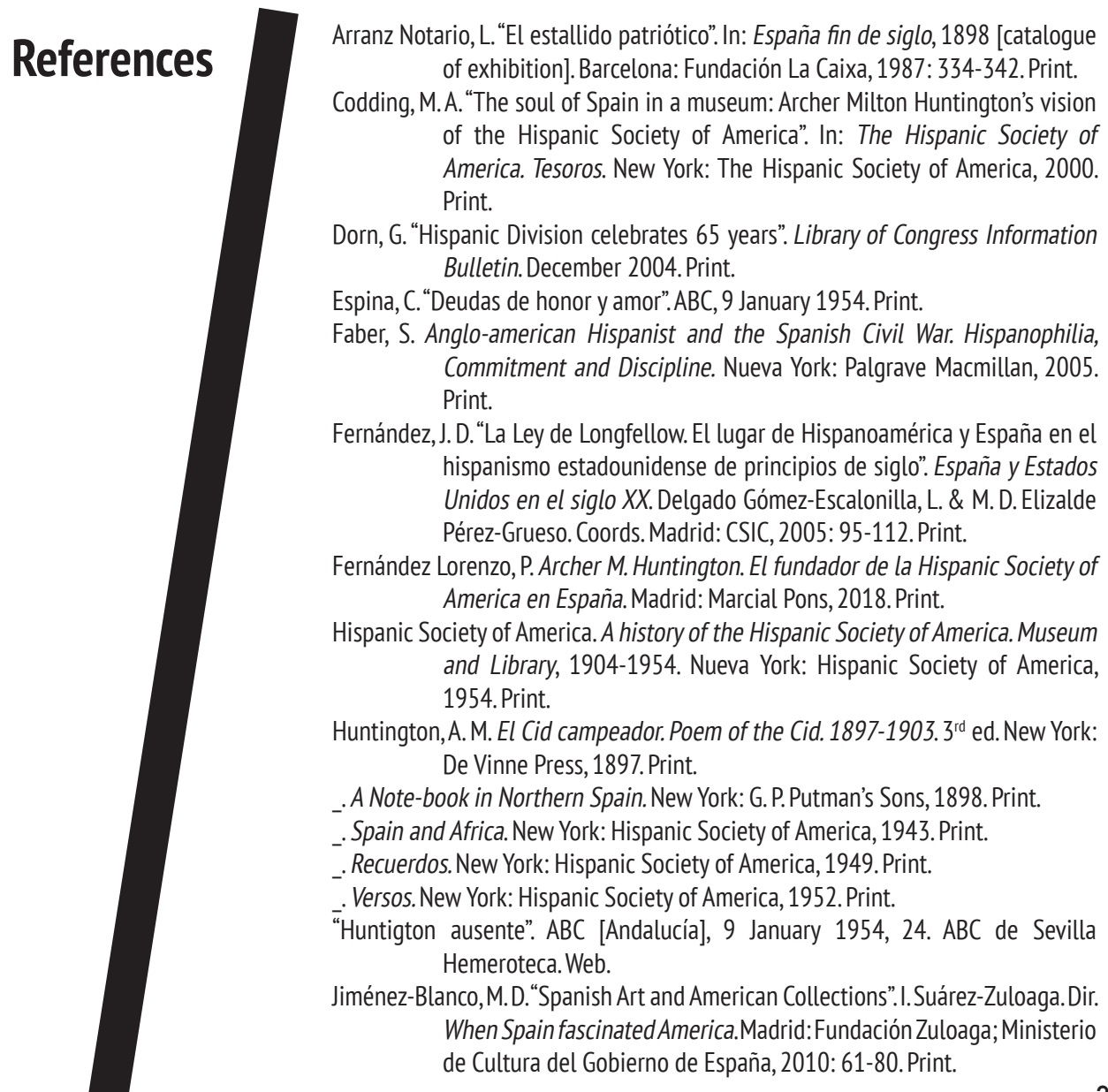


Kagan, R. L."The Spanish Craze: the discovery of Spanish art and culture in United States". I. Suárez-Zuloaga. Dir. When Spain Fascinated. Madrid: Fundación Zuloaga; Ministerio de Cultura del Gobierno de España, 2010: 25-46. Print.

Mitchell,M. \& A.Goodrich. The Remarkable Huntingtons.Archer and Anna. Chronicle of a Marriage. Pawleys Island: Litchfield Books, 2008. Print.

Montero Jiménez,J. C. El despertar de la gran potencia: las relaciones entre España y los Estados Unidos (1898-1939). Madrid: Biblioteca Nueva, 2011. Print.

Hispanic Society of New York. “A. M. Huntington's view”. New York Herald. 6 April 1896. Print.

Proske, B.G. Archer M. Huntington. New York: The Hispanic Society of America,1963. Print.

Roca Barea, E. Imperiofobia y Leyenda Negra. Roma, Rusia, Estados Unidos y el Imperio español. Madrid: Siruela, 2019. Print.

Rubio, D. “Mementos". Huntington 1870-1955. Washington: Organización de Estados Americanos-Comité Interamericano de Bibliografía. Pan American Union, 1957: 34-37. Print.

Serviddio,F."Los murales de Portinari en la sala Hispánica del Congreso de Estados Unidos: construcción plástica de una identidad panamericana". Cuadernos del CILHA, 12:14.(2011): 121-150.Print.

Socias Batet, I. El memorial de Barcelona a Archer Milton Huntington, el fundador de la Hispanic Society of America, y a su esposa, la escultora Anna Hyatt Huntington. Barcelona: Publicacions i Edicions de la Universitat de Barcelona, 2009. Print.

Tesoros arqueológicos de la Hispanic Society [catalogue of exhibition]. Madrid: Museo Arqueológico Regional, 2008. Print.

Wellesley College. Estudios Hispánicos. Homenaje a Archer M. Huntington. Mexico: Wellesley College, 1952. Print.

\section{Personal Correspondence \\ Huntington Diaries, 1898. Hispanic Society of America: New York. The Diaries are located in the Huntington Archive at the Hispanic Society of America and archived chronologically so date citations are the only form of reference made to these sources. \\ Letter from Archer Huntington to the Duke of Alba, 18 April 1938. Anna Hyatt Huntington Papers. Special Collections Research Center. Syracuse University Library. Box 7. \\ Letter of Archer Huntington to Archibald McLeish, 10 June 1940. Anna Hyatt Huntington Papers. Special Collections Research Center. Syracuse University Library. Box 43. \\ Letter of Archer Huntington to Henry Grattan Doyle, 2 March 1926. Anna Hyatt Huntington Papers. Special Collections Research Center. Syracuse University Library. Box 31. \\ Note of Marquis de la Vega-Inclán to Alfonso XIII, 15 April 1927.Archivo General de Palacio. Reinados. Alfonso XIII. Expediente 12422/8. \\ Report of Román de la Presilla, cónsul of Spain in New York, to Juan de Bárcenas, General Director of Foreign Affairs, 2 February 1954. AMAEC R. 3585, Expediente 28. \\ The Hispanic Society of America. Foundation Deed, p. 2.}

